\title{
SHOPPING FOR APPAREL: HOW CAN KIOSK SYSTEMS HELP?
}

FAZER COMPRAS DE ROUPAS: COMO O SISTEMA DE QUIOSOUES PODE DAR APOIO?

\author{
HACER COMPRAS DE ROPA: ¿CÓMO EL SISTEMA DE QUIOSCOS PUEDE DAR APOYO?
}

\section{ABSTRACT}

When shopping for apparel, many consumers seek advice from friends and family or store personnel. In-store kiosk systems might serve as an alternative decision support system. In the present study we address the key question of how such kiosk systems are evaluated by consumers. We conducted three focus group discussions with regular apparel shoppers aged between 23 and 39 years. In sum, qualitative information from 15 participants was subject to a qualitative content analysis with the aim of gaining a more comprehensive understanding of how apparel shoppers experience the shopping process. Getting a more in-depth understanding of the needs and wishes associated with the apparel shopping process gives a basis for evaluating the potential acceptance of electronic decision support systems in apparel shopping.Although our study is exploratory in nature, we are able to draw an initial picture of how kiosk systems could be used in apparel shopping.

KEYWORDS Apparel shopping, qualitative study, kiosk systems, acceptance, innovation

Monika Koller monika.koller@wu.ac.at

Professor at Institute of Marketing-Management, Vienna University of Economics and Business, Austria

Andrea Königsecker a.koenigsecker@gmx.at

Graduate at Institute for Marketing-Management, Vienna University of Economics and Business, Austria

Resumo Ao fazer compras de roupas, muitos clientes buscam conselho dos amigos, da família ou dos vendedores da loja. Os quiosques podem servir de sistema alternativo de apoio à decisão. Apresentamos a questão principal quanto à maneira pela qual os sistemas de quiosques são avaliados pelos clientes. Desenvolvemos três discussões com clientes regulares de roupas, com idades entre 23 e 30 anos. Em resumo, as informações qualitativas decorrente dos 15 participantes, foram sujeitas a uma análise de conteúdo qualitativa, com o intuito de ganhar uma compreensão mais completa de como os clientes podem experimentar o processo de fazer compras. Uma compreensão das necessidades e desejos associados às compras de roupas fornece a base de avaliação da possibilidade de aceitação dos sistemas eletrônicos de apoio à decisão na compra. Apesar de tratar-se de um estudo exploratório, é possível traçar um panorama inicial da maneira de utilização dos sistemas de quiosques para fazer compras de roupas.

Palavras-chave Compras de roupas, estudo qualitativo, sistemas de quiosque, aceitação, inovação.

Resumen Al hacer compras de ropa, muchos clientes buscan consejo de los amigos, de la familia o de los vendedores de la tienda. Los quioscos en la tienda pueden servir de sistema alternativo de apoyo a la decisión., Presentamos la cuestión principal respecto a la manera por la cual los sistemas de quioscos son evaluados por los clientes. Desarrollamos tres discusiones con clientes regulares de ropa, de edades entre 23 y 30 años. Las informaciones resultantes de los 15 participantes fueron sometidas a un análisis de contenido cualitativo, con la intención de obtener una comprensión de cómo los clientes pueden experimentar el proceso de hacer compras. Una comprensión de las necesidades y deseos asociados con las compras proporciona la base de evaluación de la posibilidad de aceptación de los sistemas electrónicos de apoyo a la decisión en la compra. A pesar de tratarse de un estudio exploratorio, se puede esbozar un panorama inicial de la manera de utilización de los sistemas de quioscos para hacer compras de ropa.

Palabras clave Compras de ropa, estudio cualitativo, sistemas de quioscos, aceptación, innovación. 


\section{INTRODUCTION}

"Looking-glass upon the wall, who is fairest of us all?" Almost every child is familiar with the popular saying in the famous fairy tale, "Snow White", by the Brothers Grimm (BROTHERS GRIMM; www. grimmstories.com). Some shoppers for apparel would be thankful if the mirror in the store spoke to them and helped them decide which clothes to buy. Mainstream technology in apparel shopping has not advanced to intelligent, talking mirrors yet, but kiosk systems might be suitable to serve as decision support system for shoppers. Both marketing practice and research have indicated that consumers are becoming more and more dissatisfied with the current market offerings in apparel (ANDERSON-CONNELL, URLICH, BRANNON, 2002). Shopping for apparel and fashion is more than a basic necessity in the lives of numerous people (HOLMLUND, HAGMAN, POLSA, 2011). Hence, apparel shoppers are constantly searching for new and alternative opportunities to best satisfy their needs.

One alternative path is the internet, which serves as a convenient shopping channel that allows shopping 24 hours, 7 days a week, in the comfort of one's own home (DAWSON and KIM, 2010). However, when shopping for apparel, next to traditional advertising and information gathering through the internet, traditional window shopping still ranks high among consumers' preferences (ACNielsen, 2006). Therefore, traditional retailers are advised to make use of the fact that customers still love the traditional approach of going in-store shopping, as well as making use of various technology-driven opportunities via the internet. Retailers should provide their customers with new and alternative offerings on site, directly at the physical point of sale (POS). One possible offering of this kind would be an electronic kiosk system positioned inside the store. Kiosks located at the POS can supplement the internet as the growing technology-driven information channel of the present day. Evaluating such in-store kiosk systems from a consumer's perspective is the core focus of the present study. Hence, qualitative material is collected in an exploratory manner in order to get a more comprehensive understanding of the needs and requirements of apparel shoppers. Based on the findings, implications for a potential introduction of kiosk systems are discussed within three focus groups. Finally, managerial implications for retailers in the clothing industry are derived.

\section{THEORETICAL FRAMEWORK}

According to Rowley (1995, p. 32), "[m]ultimedia kiosks are workstations which are specifically designed for public access. They may be standalone or networked through to a larger computer system. [...] 'multimedia' implies that they present information in a variety of different media, including, for example, text, sound, graphics, images and video. [...] Multimedia kiosks are an attractive and interesting means of presenting information, and have been used in advertising, retailing, banking, education and training and the provision of information and advice.".

Tung (1999, p. 273) defines information kiosks as "[...] machines that can disseminate information, handle transactions or perform both functions". Kiosks are used to provide information and services directly to the customer (ROWLEY and SLACK, 2003). Placed in store, retailers use them as an alternative channel for delivering their services, offering specific information and the completion of retail transactions (DE MOERLOOSE and others, 2005). Based on a typology suggested by Tung and Tan (1998), information kiosks can be classified into four different types, based on the following two dimensions: (1) transaction orientation and/or (2) information dissemination. Hence, four types can be detected in a 2x2 matrix: low transaction/ low information dissemination, high transaction/ low information dissemination, low transaction/high information dissemination, and high transaction/high information dissemination. Depending on whether a kiosk will be used for disseminating information only or also to manage purchase transactions, the technical features may vary (SLACK and ROWLEY, 2002). All possible types of kiosks may be used to maintain or even increase strategic competitiveness. When implementing kiosk technologies, Tung and Tan (1998) suggest that the application implemented on the kiosk should match the type of kiosk and be suitable for kiosk users. For instance, a kiosk system used to advertise and/or sell apartments may comprise a virtual tour around the apartments. The ability to bring the product directly to the customer is a value-added service (TUNG and TAN, 1998). In a fashion store, all four types of kiosk systems could be implemented. However, any managerial decision over which type of kiosk to employ (transaction or information oriented or both) should be in line with the store's general marketing strategies regarding communication and transaction channels. 
In sum, various types of kiosk systems used in store aim at enhancing perceived service quality and satisfaction with the purchase decision-making process. Moreover, they may enhance the shopping experience. Recent insight from neuroeconomics underlines the predominant role of emotions in making decisions (PHELPS, 2009). Hence, in-store technologies such as kiosk systems, offered to increase the shopping experience, might be worth a closer look. Following the reasoning of previous literature on the perceived value/loyalty link (see, e.g., CRONIN and others, 2000), increased affectively-toned value perceptions during the shopping process might also lead to enhanced loyalty towards the retailer. In general, previous research suggests that information technology may be able to improve service quality (BERKLEY and GUPTA, 1994). Regarding the specific case of using information kiosks in retail, a study conducted by de Moerloose and others (2005) in Belgium suggests that, in general, implementing kiosk systems might be an advantageous endeavour for a retailer. However, they also identified some potential disadvantages and obstacles that a retailer should be prepared to tackle when implementing instore kiosk systems. Previous literature has discussed the relevance of electronic kiosk systems in various industries, such as tourism, travel, financial services and food retailing (TUNG, 1999; SLACK and ROWLEY, 2002; DE MOERLOOSE and others, 2005).

However, empirical data on the role of electronic kiosk systems in apparel shopping from a consumer's perspective is still scarce. The seminal work by Burke (2002) provides a first insight into how customers evaluate various technologies used in stores. In the case of apparel shopping, the results presented by Burke in 2002 already point to in-store kiosks having a certain amount of potential, although the customers did not rate them as a "must have" feature. Moreover, when shopping for apparel, consumers are looking for an enjoyable and entertaining shopping experience (BURKE, 2002). In-store kiosks could contribute to such an experience. However, this might only be accomplished if the consumers experience them as easy to use and adding value. Therefore, more research is vital on the features and characteristics consumers would look for in a kiosk system. Core variables of the technology acceptance model (TAM), such as ease of use, perceived usefulness and perceived relative advantage, might be relevant factors in this regard.

Hence, the present study is classified into the stream of literature on consumer acceptance of new (self-) service technologies (see further, e.g., DAVIS, 1989; DAVIS, BAGOZZI, WARSHAW, 1989; MEUTER and others, 2000; MEUTER and others, 2005). Especially, a multidimensional view of perceived relative advantage, similar to the multidimensional value perceptions suggested by Sweeney and Soutar (2001), seems promising. It seems reasonable to expect that interactions with in-store kiosk systems in apparel shopping might elicit value perceptions along various dimensions, such as functionality, economical aspects, and emotional or hedonic aspects. Especially in apparel shopping, information kiosk systems placed in stores might complement service personnel and help customers during the entire purchase decision-making process. Recently published market research data on the major issues that might scare apparel shoppers off points to unfriendly personnel, pushy personnel, long queues at dressing rooms and/or check-outs, incompetent personnel, and poor air conditioning at the POS (either too hot or too cold) (GfK, 2006). Faced with these results, in-store kiosk solutions might assist in reducing unsatisfactory experiences for customers, by addressing these domains.

Within its "Future Store Initiative", the Metro Group recently started to test smart solutions in apparel retail, based on RFID (radio-frequency identification) technology (METROGROUP, 2011). So-called "smart mirrors" and "smart dressing rooms" were implemented in a test setting, offering additional services to apparel shoppers. Pieces fitted with a RFID tag make it possible for the customer to receive additional information on a display in the dressing room. Additional information would comprise prices, materials, care instructions, suggestions for matching accessories and possible combinations, as well as the sizes and colours available (METROGROUP, 2011). This initiative is a perfect example of how a kiosk system could be used in apparel shopping in the future. However, at the moment, broad applications in the field are scarce and so is the scientific knowledge on how such initiatives would be evaluated by the average apparel shopper.

Previous research on the intention to use retail service innovations in general and kiosk technology in particular suggests that there is considerable heterogeneity among potential users. The relevant antecedents predicting the intention to use these kinds of systems, such as performance expectancy, effort expectancy, facilitating conditions and social influence, vary according to whether the individuals are described as potential or early adopters (CHIU, FANG, TSENG, 
2010). Hence, Chiu and others (2010) strongly advise retailers to choose a segment-oriented approach when promoting innovative retail technologies. Moreover, in the specific case of shopping for apparel and fashion, we expect heterogeneity not only regarding the technological aspects of kiosk systems. We know from extensive research on the purchase decisionmaking process for clothing that the needs and wishes among customers are diverse, depending on age, gender, design preferences and so on (BIRTWISTLE and TSIM, 2005; HOLMLUND, HAGMAN, POLSA, 2011). Burke (2002) also finds that younger adults are more interested in new technologies in consumption contexts, particularly in regards to interactive kiosks through which they might find out more about new products, search for product information or compare alternatives. Therefore, we also expect that there might be different customer segments in terms of whether electronic kiosk systems will make the process of apparel shopping easier and more pleasurable. Cultural differences might also affect the acceptance of in-store kiosks in apparel stores. Choi and others (2012) point to cultural differences when it comes to the acceptance of self-check-in kiosks (CHOI, CHO, KAZDA, 2010). Hence, cultural background might be another source of heterogeneity related to the evaluation of in-store kiosk systems in apparel shopping. The qualitative approach of this study makes it impossible to actually test for heterogeneity among the variables predicting actual in-store kiosk use in apparel shopping. This remains for further research. However, the qualitative approach selected in this study provides other advantages, such as a more in-depth understanding, and generating more creative ideas of how kiosk systems might contribute to enhanced evaluations of the shopping experience. The exploratory approach cannot provide findings that are generalizable to a broader population of shoppers or to other industries. However, it provides initial insights into the topic under scrutiny.

\section{EMPIRICAL DESIGN AND METHODOLOGY}

The empirical design of this study followed a two-step qualitative approach. In the first step, observation was used to get a more comprehensive understanding of in-store behavior and the characteristics of relevant target groups for the subsequent focus group discussions. The second step comprised three focus group discussions. The empirical design of these two steps are described in more detail below.

\section{Step 1 - In-store observation}

The aim of this first step was to get a more detailed feeling for the core characteristics of different segments of apparel shoppers who would be suitable participants in the focus group discussions. The observation was conducted within a single week at the POS of four different European retail chains, differing in terms of the size of product range offered and their target markets. The stores were located in either Vienna or St. Pölten, two state capital cities in Austria. To gain a broader picture of potential participants, we observed on different days in the week and at different times each day. The detailed schedule was as follows: Tuesday from 02:30 to 02:45 pm, Wednesday from 10:45 to 11:00 am, Thursday from 11:00 to 11:15 am and 05:30 to 05:45 pm, and Saturday from 01:30 to $01: 45 \mathrm{pm}$ and $03: 15$ to $03: 30 \mathrm{pm}$. Through this approach, we aimed to get a good grasp of the target group we were interested in for the present study.

It is also important to note that none of the stores observed actually had an in-store kiosk system. However, this did not place any limitations on the observation as its core aim was to get a better understanding of the demographic characteristics of the apparel shopper. In this first step, we did not intend to actually observe customers' interaction with in-store kiosks. Neither did we aim to analyze any other store layout characteristics or customer perceptions related to them. Pre-defined characteristics, such as gender, estimated age, and whether the individual was shopping alone or with a group of other people, were noted. However, we did not keep track of the process by which they found and selected garments, nor did we have the opportunity to observe the actual use of kiosk systems by the customers, due to the lack of these systems in the stores in question. Finally, observations regarding the shop layout are not a part of the present study and were therefore explicitly excluded from the design of the observation process. The in-store observation yielded the following results: In total, 495 individuals were observed. 76.6\% were female, and $23.4 \%$ were male. The majority of people were shopping in a group of two. The individuals were also clustered into estimated age groups. The classification of apparel shoppers based on this exploratory observation was the basis for recruiting relevant participants for the subsequent focus group discussions. 


\section{Step 2 - Focus group discussions}

Three different focus groups were conducted. Each focus group was moderated by the same academic, based on a standardized interview guide. The interview guide was established based on extant knowledge of the factors relevant to the acceptance of kiosk systems, derived from our literature review. However, as details on the acceptance of kiosk systems in the particular field of apparel shopping were found to be still scarce, the interview guide had to be adapted to this situation. Hence, several topical areas and related interview questions were developed ad hoc as well. The focus groups were held in German to ensure that the participants were not distracted by having to translate their thoughts into English. Each focus group lasted about 60 minutes, and was audio-taped and transcribed.

The transcripts formed the basis for a qualitative content analysis of the collected interview data (MAYRING, 2003). In a first step, coding of the original material and data analysis was carried out by two academics, separately. In a second step, the outcomes of step 1 were compared, and discussed, and led to a joint version of the aggregated results. This process contributed to the scientific quality of collecting, analyzing and interpreting the qualitative consumer data. Data reduction was carried out by coding original statements and then grouping them into related topical fields. Data were first aggregated and analyzed within, and subsequently across, focus groups.

In all, 15 regular apparel shoppers participated in our three focus groups. The first group consisted of 6 , the second of 5 , and the third of 4 participants. The recruitment of participants followed a purposive sampling approach. Postings were distributed via social media platforms. To facilitate the organization and scheduling of the focus groups, the internet scheduling tool, "doodle", was used (DOODLE; www.doodle. com). Based on the results of our initial observation task, two thirds of the participants we recruited were female. The ages of the participants ranged from 23 to 39 years. In the end, we found out that 13 of the 15 participants already had experience with some kind of kiosk system before the focus groups took place. However, previous experience with such systems was explicitly not a prerequisite for participation, as we did not want to provide too much information to the participants before the actual discussion, in order to avoid any kind of demand effect. Therefore, the information provided by the focus group participants was based on their previous experience with real kiosks in various settings, as well as on their ideas of what an ideal kiosk in a fashion store should be like. Regarding the technology-friendliness of the participants, it can be noted that the participants covered a whole range of levels. Hence, as well as those with a medium level of interest in new technologies, extremely techaffine participants as well as tech-reluctant people participated. This mix of participants scoring differently regarding tech-friendliness allowed us to capture a more realistic picture of the topic under scrutiny.

Each of the participants indicated that he/she had previously had a negative experience of having left an apparel shop having bought nothing and being dissatisfied with the shopping experience, at least once. Reflecting on how much time they would usually spend in an apparel shop, eight of the participants mentioned an average duration of between 1 and 30 minutes and seven of them an average duration of between 30 and 60 minutes. On average, they reported spending about $€ 59$ on each shopping trip. In the interview guide, two core discussion topics were addressed: (1) a reflection on previous positive and/or negative experiences when shopping for apparel; (2) an evaluation of in-store kiosk systems in apparel shopping.

\section{EMPIRICAL RESULTS}

In the first section of the focus group discussion, the participants were asked to report and reflect on previous shopping trips for apparel. In the following, statements given by focus group participants are presented in italics, in quote marks (original German statements were translated into English).

\section{Previous shopping experiences}

In general, the participants reported that sometimes they loved to just browse and stroll, but at other times they would actively search for specific products and stores. The overall shopping behavior turned out to depend on specific situations, and the external environment, for each individual shopper. For instance, if they needed to shop for a specific type of clothing, a new party outfit for example, the search process would be more structured.

One key topic that emerged in all three focus groups was the role of store personnel. Participants reported that they had had negative experiences with 
sales people who were too pushy. Some participants expressed the feeling that sales people had spun them a line or said that there was something wrong with the deal they got in the end. Especially when just strolling and browsing, they felt that being asked questions by store personnel immediately they entered a store was very annoying. They felt that someone should be there to provide assistance, if they needed it, but that he or she should remain in the background until needed. If store personnel act in this way, they said, it gives them a good, secure feeling and contributes to an overall positive experience of the situation. However, the participants also reported that, if they were actively searching for something in particular, sales people should be available to answer questions and should do so competently. If no-one is available in the latter case, this might lead to a negative experience of the entire shopping process. For instance, one participant reported: "Just recently, I had been waiting in a store for more than five minutes already, standing around and already screaming loudly for assistance, but no-one turned up to help me."

Participants in the focus groups also reported that they expected store personnel to be very involved, helping to meet every customer need, even if a store was very crowded. If, for instance, a sales person answers a customer query by looking up some additional information on a PC or the internet, this is very positively evaluated. Personal, warm and friendly service is also appreciated, especially when the sales person immediately recognizes the needs of the customer and guides him/her through the decision process without being pushy.

Another important topic that emerged relates to the in-store setting, namely the store interior, including the dressing rooms and the check-out. Lighting in the dressing rooms turned out to be crucial. One participant said: "In some stores there are really, bad, really bad dressing rooms. I guess almost every woman feels like this; in these rooms you get the feeling that you have cellulite even in your face." Other topics mentioned, in terms of a shop atmosphere that had led to a negative shopping experience, were the following: a chaotic atmosphere in a store, shelves that are too narrow and crowded, sales personnel in a bad mood and unfriendly, loud debates among sales personnel having a negative halo on the overall atmosphere experienced in the store.

Another source of negative in-store experiences mentioned by the focus group participants relates to the clothes offered. Customers get annoyed if the right size is no longer available, if the quality is bad or if a particular piece that they are searching for is no longer available. Moreover, if such problems regarding the availability of alternatives or other sizes arise, they felt that the sales personnel should be immediately available to provide assistance. If not, the strength of the negative experience would be increased even further.

\section{Evaluation of kiosk systems}

The second key topic addressed in the focus group discussions was the needs and requirements associated with in-store kiosk systems in apparel shopping. As basic features, participants suggested that an in-store kiosk in an apparel store should assist them in finding different sizes, provide information on the pieces in stock, information on the location of the item in the store, and information on alternative colours in the chosen item. Moreover, some participants mentioned that such kiosks should be combined with the e-shop of the firm. The kiosk should provide an interface for ordering items unavailable in the store. For instance, customers should be able to order items directly, to be sent to their home, or ask for them to be delivered from other retail outlets to the current POS. Furthermore, the internet link should provide the possibility for the customer to check the stocks of a specific outlet online and/or reserve a particular item before he or she comes to the store. On arrival at the store, they should be able to use the kiosk to proceed with the order they started at home. Some of the participants also stated that they would like to see a self-check-out function, not necessarily directly associated with the kiosk.

The key benefit expected from a kiosk system would be a more efficient in-store search process without having to rely on the assistance of the sales personnel. Another expected benefit would be a better and more efficient decision support service through the electronic information available. The following emerged as essential factors for the acceptance of a kiosk system: the presence of a barcode scanner to read in the selected items quickly and easily, an easy-to-use touch screen, up-to-date data, and sufficient terminals available to avoid queues. The focus group participants also mentioned that, when kiosk systems are introduced by a retailer, they expect to receive assistance in using them at first. Sales personnel should be available if any questions arise during usage. The participants were concerned that these aspects could be especially critical for elderly shoppers.

Moreover, the data and information provided by a kiosk should be screened by experts so that only the most essential information is included. Too 
much information might lead to confusion for less experienced customers. Kiosks should only be offered in addition to sales personnel. Some of the participants also mentioned ethical issues and issues related to the protection of personal data. These issues would need to be addressed by the issuing retailers prior to the introduction of kiosk systems. In the case of combining kiosk systems with customer loyalty cards, additional costs should not be passed on to the customers. Some of the focus group participants also mentioned more extreme features that could be provided by kiosk systems. For instance, one participant suggested: "If a retailer was really, really cool, the firm could offer fitting rooms with a body scanner included. In that case I wouldn't even have to try the clothes on any more."

\section{DISCUSSION AND IMPLICATIONS}

Shopping for apparel is not as straightforward for every consumer as one might expect. Previous research has already suggested that shopping for apparel and fashion represents a very special purchase decisionmaking process. In the present study, we have had a closer look at the role of in-store kiosk systems in the context of apparel shopping. A two-step qualitative research approach was applied. Due to the characteristics associated with such an approach, our findings are exploratory only. However, applying the focus group methodology enabled us to get a more in-depth understanding of the needs and requirements of apparel shoppers. The most frequently mentioned sources of negative shopping experiences were related to in-store characteristics, the clothes chosen, and the sales personnel. Regarding all three of these major topics, in-store kiosk systems offered in addition to sales staff could help to resolve these problems. In-store kiosks are viewed as serving as an alternative source of information only. This is a major finding of our study. Moreover, there is heterogeneity among consumers regarding how the role of a kiosk system is evaluated. Such evaluations also depend on the situation and the type of purchase decision-making process. In certain situations, kiosks might help to cut queues at dressing rooms and cash desks. In combination with internet applications by the retail chain, kiosks might offer new ways of serving the customer, but also of customer to business communication.

Regarding managerial implications, when introducing in-store kiosk systems, the retailer should refrain from a "one-size-fits-all" strategy. Kiosk systems can help to enhance satisfaction with the purchasing process in certain environments and for certain customer needs. Given the findings presented by Choi and others (2010) related to self-check-in kiosk use, potential cost savings related to in-store kiosks in fashion stores might not be realized if the kiosks do not meet customer needs. Burke (2002) also stresses the potential caveat that retailers must be cautious in adopting new technologies as many innovations do not deliver sufficient added value to the consumers. This suggests the need for customer-integrated approach in terms of value cocreation when it comes to the implementation of instore technologies. Such an approach would seem more successful than simply implementing new technological solutions without directly integrating the customers' needs. Moreover, providing sufficient performance in the core categories for a retailer, for instance in terms of the friendliness and competence of sales personnel, is still a must. In addition to these core elements, kiosk systems can be used as factors to aid consumer delight. Special assistance should be provided for elderly shoppers. Issues such as data security should be dealt with beforehand. When combined with customer loyalty cards, data processing needs to remain transparent to consumers. The additional advantage of using such a system needs to be visible and communicated by the retailer. The information provided by the systems needs to be up to date and the usability of the kiosks needs to be guaranteed.

To sum up, our exploratory findings indicate that in-store kiosk systems may provide additional potential for increasing customer satisfaction and perceived service quality in apparel shopping. However, retailers need to be cautious and tackle the potential obstacles involved in an area-wide introduction of such systems. If the heterogeneous customer needs are not sufficiently addressed, kiosk systems might become another source of dissatisfaction for apparel shoppers during the purchase decision-making process.

\section{LIMITATIONS AND AVENUES FOR FUTURE RESEARCH}

As with most research, this study has its limitations. First, the study is limited to a qualitative approach. The relevant topics highlighted in our exploratory study 
need to be rechecked using a quantitative approach. Only the latter can provide insights into whether the findings are relevant to a broader population. Moreover, previous research on the acceptance of self-service technologies in general suggests that variables such as perceived ease of use and perceived usefulness have a major impact on whether self-service technologies are accepted by customers (DAVIS, 1989; DAVIS, BAGOZZI, WARSHAW, 1989; MEUTER and others, 2000; MEUTER and others, 2005). Moreover, personality characteristics such as technology anxiety may have an impact on how kiosk systems are perceived and to what degree customers are ready to use them (OYEDELE and SIMPSON, 2007; ZHAO, MATTILA, TAO, 2008). We assume that there might be heterogeneous customer segments regarding the willingness to use such systems. Moreover, customers might also differ regarding the benefits they expect to get from using these systems. Park, Kim and Forney (2006) conclude that retailers should pay more attention to their customers' positive emotional states and hedonic in-store experiences, since these factors may trigger impulse buying of fashion products. Further quantitative research should test whether providing the possibility to use in-store kiosk systems can actually enhance the perceived hedonic value of the shopping experience and/or purchasing behaviour. These questions should be addressed in a quantitative, empirical design in more detail.

Second, our study addressed the topic of shopping for apparel. Further research should expand our approach by including related industries such as shopping for shoes, accessories or other highinvolvement products, such as luxury labels.

Third, another qualitative approach could help to gain deeper insights into selected topics pinpointed by the present study. For instance, further focus group discussions should include a prototype of a kiosk system that the participants could try out during the process. This approach would provide a higher level of external validity and complement the findings of our present qualitative study.

Fourth, further research should address the question of consumer acceptance of various mobile applications, such as barcode scanning apps like Bakodo (BAKODO; www.bako.do), in general, and in comparison to instore kiosk solutions in apparel stores, in particular.

Fifth and finally, from a marketing management perspective, retailers should investigate in more detail the role of in-store kiosk systems used in apparel stores for boosting customer satisfaction and perceived service quality. Having more comprehensive knowledge on whether offering such kiosk systems can actually enhance customer satisfaction and other purchaserelated consumer behaviour constructs could lead to a strategic advantage compared to competitors. Moreover, in the long run, it may also be reflected in hard facts such as increased sales and the economic growth of the firm.

\section{REFERENCES}

ACNIELSEN, 2006. Available at http://www.wisonet.de/ webcgi?START $=$ A60\&DOKV_DB=FAKT $\& D O K V \_N O=N 07-$ 0707\&DOKV_HS=0\&PP=1. Access on August.4.2011.

ANDERSON-CONNELL, L. J; ULRICH, P. V; BRANNON, E. L. A consumer-driven model for mass customization in the apparel market. Journal of Fashion Marketing and Management, v. 6 n. 3, p. 240-258, 2002.

BAKODO. Available at www.bako.do. Access on July.9.2012.

BERKLEY, B. J; GUPTA, A. Improving service quality with information technology. International Journal of Information Management, v. 14, n. 2, p. 109-121, 1994.

BIRTWISTLE, G; TSIM, C. Consumer purchasing behaviour: an investigation of the UK mature women's clothing market. Journal of Consumer Behaviour, v. 4, n. 6, p. 453-464, 2005.

BROTHERS GRIMM, 'Snow-white'. Available at http://www. grimmstories.com/language.php?grimm=053\&l=en\&r=de. Access on August.5.2011.

BURKE, R. R. Technology and the customer interface: what consumers want in the physical and virtual store. Journal of the Academy of Marketing Science, v. 30, n. 4, p. 411432, 2002.

CHIU, Y.-T. H.; FANG, S.-C; TSENG, C.-C. Early versus potential adopters. Exploring the antecedents of use intention in the context of retail service innovations. International Journal of Retail \& Distribution Management, v. 38, n. 6, p. 443-459, 2010.

CHOI, HS C; CHO, J; KAZDA, P. The effect of culture differences on self check-in kiosk use: an empirical study 
of Canadian travellers. International Journal of Tourism Sciences, v. 10, n. 2, p. 117-152, 2010.

CRONIN, J. J, BRADY, M. K, HUlT, G. T. M. Assessing the effects of quality, value, and customer satisfaction on consumer behavioral intentions in service environments. Journal of Retailing, v. 76, n. 2, p. 193-218, 2000.

DAVIS, F. D. Perceived usefulness, perceived ease of use, and user acceptance of information technology. MIS Quarterly, v. 13, n. 3, p. 319-340, 1989.

DAVIS, F. D; BAGOZZI, R. P; WARSHAW, P. R. User acceptance of computer technology: a comparison of two theoretical models. Management Science, v. 35, n. 8, p. 982-1003, 1989.

DAWSON, S; KIM, M. Cues on apparel web sites that trigger impulse purchases. Journal of Fashion Marketing and Management, v. 14, n. 2, p. 230-246, 2010.

DE MOERLOOSE, C; ANTIOCO M; LINDGREEN, A; PALMER, R. Information kiosks: the case of the Belgian retail sector. International Journal of Retail \& Distribution Management, v. 33, n. 6, p. 472-490, 2005.

DOODLE. Available at www.doodle.com. Access on July. 9.2012 .

GfK, 2006. TW-Kundenmonitor "Die Todsünden des Modehandels". Available at http://www.textilwirtschaft. de/business/markt/marktfakten/twstudien/kundenmonitor/ pages/showphp?id=15. Access on August.5.2011.

HOLMLUND, M; HAGMAN, A; POLSA, P. An exploration of how mature women buy clothing: empirical insights and a model. Journal of Fashion Marketing and Management, v. 15 n. 1, p. 108-122, 2011.

MAYRING, P. Qualitative Inhaltsanalyse, Beltz UTB, Weinheim und Basel, 2003.

METROGROUP, 2011. The dawn of a new shopping age. Available at http://www.future-store.org/fsi-internet/html/ en/1613/index.html. Access on August.5.2011.

MEUTER, M. L; BITNER, M. J; OSTROM, A. L; BROWN, S. W. Choosing among alternative service delivery modes: an investigation of customer trial of self-service technologies. Journal of Marketing, v. 69, n. 2, p. 61-83, 2005.
MEUTER, M. L; OSTROM, A. L; ROUNDTREE, R. I; BITNER, M. J. Self-service technologies: understanding customer satisfaction with technology-based service encounters. Journal of Marketing, v. 64, n. 3, p. 50-64, 2000.

OYEDELE, A; SIMPSON, P. M. An empirical investigation of consumer control factors on intention to use selected self-service technologies. International Journal of Service Industry Management; v. 18, n. 3, p. 287-306, 2007.

PARK, E. J; KIM, E. Y; FORNEY, J. C. A structural model of fashion-oriented impulse buying behavior. Journal of Fashion Marketing and Management, v. 10, n. 4, p. 433446, 2006.

PHELPS, E. A. The study of emotion in neuroeconomics. In Neuroeconomics. Decision making and the brain. Glimcher, P.W; Camerer, C.F; Fehr, E; Poldrack, R. A. (eds), London: Elsevier, p. 233-250, 2009.

ROWLEY, J. Multimedia kiosks in retailing. International Journal of Retail E Distribution Management, v. 23, n. 5 , p. 32-40, 1995.

ROWLEY, J; SLACK, F. Kiosks in retailing: the quiet revolution. International Journal of Retail \& Distribution Management, v. 31, n. 6, p. 329-339, 2003.

SLACK, F; ROWLEY, J. Kiosks 21: a new role for information kiosks?. International Journal of Information Management, v. 22, n.1, p. 67-83, 2002.

SWEENEY, J. C; SOUTAR, G. N. Consumer perceived value: the development of a multiple item scale. Journal of Retailing, v. 77, n. 2, p. 203-220, 2001.

TUNG, L. L. The implementation of information kiosks in Singapore: an exploratory study. International Journal of Information Management, v. 19, n.3, p. 237-252, 1999.

TUNG, L. L; TAN, J. H. A model for the classification of information kiosks in Singapore. International Journal of Information Management, v. 18, n. 4, p. 255-264, 1998.

ZHAO, X; MATTILA, A. S; TAO, L.-S. E. The role of posttraining self-efficacy in customers' use of self -service technologies. International Journal of Service Industry Management, v. 19, n. 4, p. 492-505, 2008. 